\title{
Catalunya entre el redreç i la revolta: afebliment institucional i diferenciació social
}

\author{
Jaume Dantí i Riu \\ Universitat de Barcelona. Departament d'Història Moderna \\ jdanti@ub.edu
}

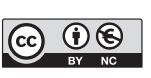

Rebut: novembre de 2012

Acceptat: desembre de 2012

\section{Resum}

$\mathrm{Al}$ darrer quart del segle XVII, Catalunya es va moure entre un redreç econòmic important - però no pas sense dificultats, durant el qual es consolidà una relació fonamental entre el món urbà i una part significativa del món rural- i una revolta oberta al camp, la dels Barretines, però amb tensions latents bastants més extenses, on convergien motivacions economicosocials $\mathrm{i}$ polítiques. Amb tot plegat i les consequiències de les guerres amb França, es donaven les condicions perquè l'austriacisme pogués arrelar en diferents sectors socials.

Paraules clau: Catalunya; segle XvII; redreç econòmic; Barretines; austriacisme.

Resumen. Cataluña entre el crecimiento económico y la revuelta: debilidad institucional y diferenciación social

Durante el último cuarto del siglo xviI, Cataluña se movió entre un crecimiento económico importante - aunque no exento de dificultades, durante el cual se consolidó una relación fundamental entre el ámbito urbano y una parte significativa del ámbito rural—y una revuelta desatada en el campo, la de los Barretines, aunque con tensiones latentes bastante más extensas, donde convergían motivaciones económico-sociales y políticas. Con todo ello, junto a las consecuencias de las guerras contra Francia, se dieron las condiciones para que el austriacismo pudiese arraigar en diferentes sectores sociales.

Palabras clave: Cataluña; siglo XvII; crecimiento económico; Barretines; austriacismo.

Abstract. Catalonia between the economic growth and the revolt: institutional weakness and social differentiation

During the last quarter of the 17th century, Catalonia moved between an economic important growth - though not without difficulties, during which a fundamental relation was consolidated between the urban area and a significant part of the rural area — and a revolt untied in the field: the revolt of the so-called Barretines (after the name of the Catalan cap the rebels wore). Both in the urban and in the rural areas, there were more extensive latent tensions, with converging economic, social and political causes. Because all of this, added to the consequences of the wars against France, different social sectors in Catalonia decided to choose the political option of the archduke Charles of Hapsburg. These political option has been known as «austriacism» and could take roots in different social Catalan sectors from the beginning of the XvIIIth century onwards.

Keywords: Catalonia; 17th century; economic growth; revolt of the so-called Barretines; «austriacism». 


\section{Sumari \\ 1. El redreç 3. Entre el conflicte i la fidelitat \\ 2. Condicions per a la revolta Bibliografia}

L'estudi del període que va de 1652 a 1705 esdevé clau per comprendre els principals aspectes derivats de les consequiències de la revolució catalana de 1640 i, alhora, de les causes del decantament austriacista a la guerra de Successió. S'hi manifestà amb tota claredat el nou caràcter de les relacions de la monarquia hispànica amb Catalunya després del que havia estat el trencament polític i la vinculació amb la monarquia francesa, alhora que la reintegració per la força militar. D'altra banda, es va fer evident la persistència en la voluntat centralitzadora del poder reial durant el regnat de Carles II, equiparable a la ja manifestada abans de 1640 i ben allunyada de qualsevol intenció neoforalista. En un altre ordre, esdevé essencial constatar les característiques del redreç econòmic iniciat a partir de 1660 per comprendre el creixement que es produí al segle XVIII com a consolidació d'aquell procés, més que no pas com a novetat després de l'aturada provocada per la guerra i del nou ordre borbònic. Finalment, tant dels aspectes polítics com dels econòmics i dels socials, en van sorgir les motivacions i la composició de l'austriacisme català.

L'objectiu d'aquest treball és el d'intentar oferir una visió de conjunt, sobre la qual no s'ha insistit prou, del context economicosocial i alhora de la conflictivitat política i social entre 1652 i 1690, entre l'inici de la repressió després de la secessió i l'acabament de la revolta dels Barretines. En aquell marc, és important d'assenyalar dos aspectes com a resultat dels processos respectius: d'una banda, des de la perspectiva política, el difícil equilibri de les institucions catalanes - Diputació i Consell de Cent- entre la defensa de la «constitucionalitat», percebuda com a mitjà de preservació de la legalitat i dels interessos dels ciutadans de Catalunya i de la fidelitat a la Corona de la qual depenien, i, d'altra banda, des de la perspectiva de l'estructura social, l'accentuació de la diferenciació interna, tant en el món rural com en l'urbà, com a resultat de la crisi dels dos primers terços del segle i de les diferents possibilitats d'aprofitament del redreç del darrer terç.

L'atenció que la historiografia catalana dels últims vint-i-cinc anys ha posat en la segona meitat del segle XVII és una mostra del relleu que es dóna en aquest període. D'entrada, ha permès completar i matisar l'esmentat redreç que havia exposat Vilar darrere l'epígraf «1660-1705: segon redreçament català. Renovació de l'esperit d'iniciativa» (Vilar, 1966: II, 373). En aquest sentit, s'ha avançat en la caracterització del redreç agrari, en les diferents intensitats i la diversitat cronològica en què es manifestà, així com en la feblesa que presentava en aquelles àrees sense transformacions significatives de l'estructura productiva (Serra, 1988; Duran, 1985: 7-42; Dantí, 1988). Pel que fa a la manufactura i al comerç, s'ha aprofundit en alguna de les àrees capdavanteres com ara la de Mataró i el Maresme, però sobretot en la diferent aportació del conjunt del territori a partir de la consolidació d'una xarxa principal entorn de Barcelona i d'altres xarxes secundàries que contribuïren igualment a promoure l'esmentat redreç (Oliva, 
2001; Giménez i Blasco, 2001; García Espuche, 1998, 2005; Lobato, 1995; Forns, 2004: 287-312; Duran, 2003: 61-88; Dantí et al., 2005, 2011).

Més gran ha estat encara l'atenció a la història sociopolítica i militar del període que quedava abans més eclipsat entre els dos grans esdeveniments de la guerra dels Segadors i la guerra de Successió. S'ha aprofundit en els diferents mitjans de repressió aplicats per assegurar el control de Catalunya per part del poder reial, en els efectes dels allotjaments militars i, especialment, dels successius conflictes amb França després del Tractat dels Pirineus fins l'any 1697, en l'afebliment de les institucions catalanes i en el canvi o la continuitat en els objectius de les classes dirigents del Principat entre 1640 i 1705 pel que fa a la relació amb la monarquia hispànica (Sánchez Marcos, 1983; Torras, 1991: 242-290; Serra, 2001: 71-103; Espino, 1999, 2007; Dantí, 2003: 9-24; Jané, 2009; Martí, 2009; Simon, 2011). Un relleu particular ha tingut l'estudi de la revolta dels Barretines, que ha deixat de ser «Una insurrecció oblidada del segle XvII» (Kamen, 1978: 11-28), per esdevenir el moviment social en què confluïren una bona part dels factors explicatius del període (Dantí, 1979: 79-99 i 1990; Albareda, 1988: 152-170 i 1991: 291-317; Espino, 1990: 19-38.

\section{El redreç}

L'inici del redreç demogràfic i econòmic de Catalunya a partir de 1660 és un fet inqüestionable, tot i que no fou ni continuat en el temps que restava de segle, ni generalitzat arreu del Principat. Cal tenir present l'estagnació de la segona meitat de la dècada de 1680, que, en algunes àrees, es perllonga fins entorn de 1694, manifestada tant pels efectes d'alguna crisi de mortalitat (1684-1685), com per les penúries patides en la producció agrària. En el millor dels casos, es recuperava el nivell de començament del sis-cents (Català, 1987; Pladevall i Simon, 1986: 54-56) ${ }^{1}$. El redreç fou més important a tota la zona litoral a causa de la transformació de l'estructura productiva vers una agricultura més orientada a la comercialització, amb una substitució de terres de cereal per vinya, de manera primerenca al Maresme, al Garraf i al Camp de Tarragona, però també amb la dedicació a uns altres productes, com ara els fruits secs (avellanes i pinyons) (Duran, 1985: 7-42; Serra, 1988: 205-216; Dantí, 1988: 211-222; Giménez i Blasco, 2001: 222-255). Es tractava, doncs, d'un creixement de la producció agrària per la via de l'especialització que propiciava una interrelació més gran entre l'interior i el litoral, entre el món rural i el món urbà, en el marc d'una conjuntura d'impuls de l'activitat comercial. Justament per aquelles condicions no es manifestà amb la mateixa intensitat arreu del territori, atès que es van mantenir algunes àrees estancades fins a la darrera dècada del segle. D'altra banda, en aquelles dècades, van persistir alhora dos factors que dificultaven les possibilitats de redreç: les guerres amb França, que delmaren especialment la zona nord i fins bona part de Catalunya el 1697 (Espino, 1999: 176-199), i els feixucs allotjaments militars distribuïts irregularment.

1. A part de les oscil-lacions de les collites, s'hi sumaren causes extraordinàries, com ara la plaga de la llagosta. 
En aquest context, s'han de subratllar les importants i suggerents aportacions que ha fet A. García Espuche, tant pel que respecta a l'èmfasi sobre el creixement del segle XVI, com per la constatació de la creació d'un sistema urbà entorn de Barcelona, amb el que suposava d'avançament del procés de descentralització que Vilar ja apuntava, però que, a la fi, situava a la segona meitat del segle XVII (García Espuche, 1998, 2004; Vilar, 1966: II, 387-391). Amb tot, caldria precisar que, en el perfil d'expansió descrit entre 1550 i 1640, les anàlisis més quantitatives mostren un clar canvi de tendència si més no a partir de 1620, de manera que el període de la guerra dels Segadors no fou la causa de la crisi, sinó un motiu d'agreujament (Simon, 1992: 157-180). Malgrat aquell trencament, la reordenació productiva que es realitzà a partir de 1660 va seguir una gran part de les línies traçades anteriorment, però amb un nivell de descentralització superior.

Amb la necessària redefinició del concepte urbà a la Catalunya moderna, per l'escassetat de nuclis de població que superessin el llindar dels cinc mil habitants, fent-lo extensiu a aquelles viles que en tenien entre mil i tres mil, ha esdevingut significativa la constatació que, justament com a consequiència de la crisi de mitjan segle, es consolidà una xarxa urbana principal que tenia com a centre Barcelona, però que, alhora, s'afermaven un seguit de xarxes menors, complementàries de la primera, amb més o menys autonomia, que configuraven conjuntament una xarxa urbana catalana (Dantí et al., 2005: 10). Es desplegava, així, una interrelació més gran entre el món rural i el món urbà que fou la base del desenvolupament comercial i manufacturer del segle XVIII.

A la constatació de Vilar de l'inici del redreç fora de la ciutat de Barcelona, la descentralització, s'hi afegien els efectes de la desurbanització de la manufactura provocada per la pressió fiscal més elevada i per la rigidesa gremial. Aquell era, però, un procés que també tenia lloc en altres ciutats, com ara Perpinyà, Girona, Tarragona o Vic, i que s'havia començat a desenvolupar des de finals del segle XVI. Paral-lelament, algunes d'aquelles viles o ciutats, i també d'altres, com ara Mataró, esdevenien nodes de les seves xarxes respectives amb més o menys vinculació amb la primera. Des d'aquesta perspectiva, es pot parlar també d'una certa especialització productiva, però que alhora exigia més interrelació, sobretot pel que suposava d'assegurar els productes de subsistència i, en particular, el blat.

Les característiques de les relacions que s'establiren mostren una diversitat important de comportaments. Així, Mataró i Sant Feliu de Guíxols reflectien dues dinàmiques distintes, la primera estava més vinculada a Barcelona, mentre que la segona n'estava amb Girona. De la mateixa manera, Sitges i Vilanova i la Geltrú tenien una clara dependència de la capital catalana, mentre que Reus i Salou es desenvolupaven amb molta menys influència del cap i casal. A l'interior, Vic i Vilafranca mantenien una estreta relació amb Barcelona, però, en canvi, la petita vila de Balaguer, amb una clara funció de centre de redistribució, estava clarament lligada a les terres de ponent.

Davant de la pregunta sobre l'abast del creixement i de les transformacions agràries, no hi ha dubte del canvi de conjuntura a partir de 1660, però és clar que fou desigual en intensitat, de la mateixa manera que eren limitats els canvis estructurals, d'altra banda indiscutibles a la zona litoral. És important de consta- 
tar, per exemple, que, tot i la significació de l'expansió del conreu de la vinya en aquell període, no era pas comparable al que es va produir a la segona meitat del segle XVIII a les terres del Penedès i de la Conca de Barberà.

També s'ha de tenir present l'important procés de diferenciació social interna entre la pagesia a causa del procés d'endeutament que ja s'havia accentuat durant la primera meitat del segle i que s'agreujà amb la crisi que tingué lloc a mitja centúria (Serra, 2008: 511-532). A partir de 1660, es constata la disminució del nombre de «pagesos» (els emfiteutes propietaris útils) i, per contra, l'augment del nombre de jornalers, parcers i masovers, alhora que es produïen processos de parcel-lació d'algunes propietats mitjanes i grans, la qual cosa donava com a resultat una concentració més elevada en mans dels pagesos benestants. El procés es féu extensiu arreu de Catalunya, com ho demostren els traspassos de parcel-les petitíssimes a la Conca de Barberà, la reducció de la petita propietat a Balaguer entorn de 1659 o l'augment de la propietat dels Pallarès de Talarn (Gual, 2007: 417-450; Vilalta, 1990: 89-118; Mirabet, 1989; Serra, 2004: 901920). Així mateix, apareixien nous propietaris, mercaders, alguns menestrals i fins algun noble que invertia en terres, com succeïa a l'Hospitalet de Llobregat a partir de 1658 en l'anomenat «temps dels propietaris barcelonins», mentre que els antics emfiteutes passaven a ser masovers (Codina, 1987: II, 379-525). Una dinàmica semblant s'ha constatat al Camp de Tarragona. A Valls, l'any 1659, la major part de la terra estava en mans del sector secundari (Olivé, 1989). Al Vallès, alguns dels mateixos pagesos benestants eren els que engrandien la seva propietat, però també algun menestral i fins bracers que accedien a petites parcel-les (Serra, 1988: 367-372; Dantí, 1988: 257-267). Amb tot, la inversió de capital urbà i la concentració de la propietat es feia present a qualsevol indret del Principat, tant a ponent com a les terres de Girona (Serra, 2008: 530; Gifre, 1999: 185-228).

Si el redreç en el camp va tenir limitacions, no en van ser una causa menor la persistència dels allotjaments militars, a part de la guerra. Els efectius presents a Catalunya no van disminuir ni després de la capitulació de 1652 ni tampoc a partir de 1659, amb la doble justificació política de ser necessaris per evitar un nou aixecament, així com pel fet que el Principat s'havia convertit en territori de frontera. Tal com ho deixava escrit Joan Guàrdia, pagès de Corcó: «Són-se cridadas las paus als primés dias de marts de l'any 1660 y ab tot això la terra no ha fetas ninguna demostració de alegrias, perquè los soldats may se'n són acabats de anar, ans bé tostems la contribució sempre à corragut molt fort» (Pladevall i Simon, 1986: 112). Tot i les dificultats per conèixer les xifres reals de soldats, segons A. Espino, entre 1684 i 1697, la mitjana seria de 14.000, mentre que les estades d'hivern que eren més carregoses per a la població no baixaren mai dels 11.000 entre 1691 i 1697, i sobrepassaven els 25.000 en aquesta darrera data (Espino, 1999: 201-206). Els efectes prou coneguts dels allotjaments sobre l'economia de les poblacions era múltiple, ja que, a part de les aportacions pactades o establertes, s'hi afegien els abusos amb el resultat d'esgotament de queviures, manca de menjar per als animals, esgotament de la palla, arrasament de botigues i, finalment, despoblament, tal com recollien els informes de llocs ben distants com ara Xerta, 
Sant Celoni o la Garriga ${ }^{2}$. La Diputació del General, en el seu paper de mediació i de defensa de la legalitat, corroborava aquella situació just el mes de gener de 1660, així reflectia la queixa de zones com ara el Baix Llobregat, el Camp de Tarragona, el comtat de Prades o la baronia d'Entença'

Los clamors y las llàstimas que cadaldia arriban en nostre consistori per medi dels sindichs de las universitats del present Principat, occasionades dels allotjaments dels soldats y contribucions tant grans y tant continuades, com també del pa y civades tenen bestret, nos han moguts ha suplicar a vostra excel-lència sie de son real servey manar se moderen ditas contribucions, per quant, segons les notícias tenim, ellas són de tal qualitat y aniquilan de tal manera los pobres paysans d'esta província que, a no donar-i prompte remey aliviant-los de càrrega tant pesada corria molt gran perill de despoblar-se molt gran part de la província.

D’altra banda, la repercussió econòmica dels allotjaments també esdevenia desigual, tant per l'arbitrarietat en el repartiment dels soldats entre els pobles, com per les exempcions de què gaudien els qui tenien privilegi militar, els ciutadans honrats de Barcelona, els oficials de la Diputació, els familiars del Sant Ofici, els doctors en lleis i medicina i alguns altres. Cal tenir en compte que, justament en aquell període, va augmentar el nombre de privilegis concedits. És important contemplar que, a més a més, les poblacions pagaven una quantitat que treien de la hisenda municipal per mantenir un cert nombre de soldats i d'animals. Davant d'aquella doble pressió, algunes viles i pobles decidiren cercar un «ajust», un pacte amb l'exèrcit per evitar l'allotjament a canvi d'una contribució, malgrat que sovint comportés l'endeutament del consell i la necessitat de recórrer a la fiscalitat extraordinària de la imposició d'una talla. Així doncs, la continuïtat dels allotjaments, amb la pressió fiscal derivada, es va convertir, en moltes comunitats pageses, en un veritable ròssec per aprofitar un redreç que ja de per si era limitat en algunes zones.

Pel que respecta a la recuperació de la manufactura, tal com s'ha dit, es va fer efectiva sobretot a partir de la producció descentralitzada i de l'anomenada «indústria dispersa», seguint la relativa especialització ja iniciada al segle XVI i accentuada a la segona meitat del XVII. El teixit de llana esdevenia important a l'àrea de Vic i Taradell, a la d'Olot o al Moianès; la producció de cuir d'Igualada i de Vilafranca del Penedès fornia bona part del mercat barceloní; la producció metal·lúrgica del Ripollès, sobretot de claus, s'exportava des de Barcelona i Mataró, i la producció de vidre, que es localitzava fonamentalment en aquesta vila del Maresme, abastava el mercat interior i alhora també participava en l'exportació.

Paral-lelament, sorgien les iniciatives de renovació del sector més desenvolupat, el tèxtil, en les quals es plantejava la necessitat de produir una «nova drape-

2. Arxiu de la Corona d'Aragó (ACA). Consell d'Aragó, lligall 518. Amb el dubte sobre la possible exageració en aquell tipus d'informes, la Garriga passà de 116 focs a 70 entre 1654 i 1655; Sant Celoni, l'any 1657, havia passat de 200 cases habitades a 35.

3. Dietaris de la Generalitat de Catalunya, vol. vII, p. 108. Memorial presentat al virrei marquès de Mortara el 23 de gener de 1660. 
ria», d'aprendre tècniques noves o de millorar el tint, i tot plegat vinculat amb una recuperació necessària del comerç que hauria de fer-se a través de la creació de companyies (García Espuche, 2005: 261-272). Aquell paradigma del redreç era el que volia impulsar Narcís Feliu de la Penya amb el seu Político discurso, de 1681, i el Fénix de Cataluña, de 1683, on es feia ressò de les queixes dels gremis barcelonins i de l'encara precària activitat comercial de la ciutat a diferència de temps passats, observacions que reforcen el contrast amb el que succeïa fora del cap i casal (Molas, 1977: 70-120). En la figura de Feliu de la Penya convergia l'anàlisi crítica de la situació feta des de Barcelona i el dinamisme mostrat per altres viles i ciutats catalanes. Així, cal fer notar l'estreta relació que mantenia amb la branca originària de la família a Mataró i amb Martí Piles, col-laborador seu i coautor del Fénix, botiguer de teles procedent de Vic. A partir dels anys vuitanta, però, també es consolidava la recuperació barcelonina (García Espuche, 1998: 123).

La represa comercial és la que ha merescut més atenció historiogràfica (Fontana, 1955; Martínez Shaw, 1981; Lobato, 1995; Oliva, 2001; Giménez i Blasco, 2001). L'interès principal s'havia fixat en el redreç del comerç exterior i en la relació entre Barcelona i l'àrea de més influència de la ciutat on altres nuclis van mantenir també el creixement durant el segle XVIII, com va ser el cas de Mataró. S'ha constatat també el relleu que assoliren les botigues i els botiguers de teles de Barcelona i com, entorn del seu desenvolupament, es generava una atracció de paraires cap a la ciutat (Molas, 1977: 7-46; Duran, 2003: 61-88). A part de l'evolució estrictament econòmica d'aquella activitat, esdevenen particularment significatius els estudis sobre l'ascens social dels capdavanters d'aquell procés i els decantaments polítics respectius, en la major part en l'austriacisme (Molas, 1977: 121-172).

Darrerament, a través de l'estudi de les xarxes urbanes menors entorn de la principal, així com de les relacions entre la costa i l'interior, s'ha avançat en la caracterització de l'articulació del conjunt del territori en aquell període on s'aprecia una interrelació creixent entre el món urbà i el món rural (Dantí et al., 2005: 9-40, 2011: 13-54). En aquest últim aspecte, es posa de manifest la importància de la pluriactivitat pagesa com a mitjà per al millorament de la renda i, alhora, com a factor que contribuí a assolir l'esmentat redreç (Dantí, 2008: 887-904)4.

Si bé, en el conjunt de la xarxa urbana catalana, es troben àrees interiors del Principat que desenvoluparen els seus propis espais de producció i de mercat, com ara Girona, Solsona o Cervera, esdevenen especialment il-lustratius de les característiques d'aquell redreç alguns exemples de les relacions entre l'àrea costanera i l'interior. El cas de la vila de Mataró, que assolia el títol de ciutat el 1702, ha esdevingut el paradigma del procés de transformació, relacionat amb la descentralització de Barcelona però convertida finalment en competència mercès al desenvolupament de la seva pròpia dinàmica econòmica. Tal com ha demostrat J. Giménez, es tracta d'un «microcosmos en moviment», en la mesura que, a la segona meitat del segle XVII, culmina el procés iniciat la centúria anterior que interrelacionava el canvi de l'estructura de la producció agrària, l'especialització

4. L'itinerari dels Guàrdia de Castellterçol és paradigmàtic: paraires, propietaris de terres, traginers i arrendataris del glaç a Barcelona i, ja a la ciutat, passen a ser botiguers, mercaders i privilegiats. 
manufacturera i el creixement de l'activitat comercial (Giménez i Blasco, 2001: 763).

Mataró substituí una bona part de la terra de blat per vinya com a opció vers una agricultura orientada a la comercialització. Pel que fa a la manufactura, passà d'una diversitat de petites produccions a l'especialització en el vidre i en les puntes, que es destinaven fonamentalment al mercat peninsular, amb la qual cosa ocupava l'espai que fins aleshores havien cobert les franceses, que deixaren d'arribar a la segona meitat del segle xvII. Aquests productes dinamitzaren sobretot el comerç d'importació, però també el d'exportació, amb una presència creixent de mercaders francesos i genovesos al port barceloní i amb un ascens dels mercaders mataronins, que passaren de ser representants de companyies foranes a esdevenir titulars de les seves pròpies (Giménez i Blasco, 2001: 595-651).

Tot i que les relacions entre Mataró i Barcelona eren molt intenses, malgrat les tensions esmentades, la vila va crear una xarxa pròpia cap a l'interior, especialment va establir intercanvis comercials amb el Vallès, però també amb el Ripollès. A la primera comarca, va sobresortir el proveïment de pinyons, amb el que suposava de vinculació amb aquella economia agrària, que eren exportats des del port mataroní conjuntament amb altres productes cap a ports francesos o italians i també distribuïts en diferents indrets de la Península. Alhora, Mataró abastia aquell territori de productes d'importació i de propis, com ara l'aiguardent (Dantí et al., 2011: 19-22).

Una altra àrea de relació important dels mercaders maresmencs va ser la que tenia com a centre Ripoll i que, al segle XVII, iniciava una producció metal-lúrgica creixent, de claus i d'armes de foc que sortien via Barcelona, però també per Mataró. Una part d'aquells productes s'utilitzaven en les seves mateixes drassanes i l'altra s'incorporava al comerç costaner que feien els comerciants de la vila, sobretot cap a València i Alacant (Graells, 1972). Per aquella ruta, des del port del Maresme, també es fornia una àmplia zona pirinenca de teixits, d'espècies o de pesca salada. En aquest cas, coincidien amb un dels eixos de la xarxa barcelonina, que era el que unia amb Vic i Ripoll.

Sant Feliu de Guíxols, com altres ports de la costa nord, com ara Blanes o Palamós, va registrar un canvi important de la seva activitat pels efectes de la crisi de la zona gironina, amb la qual estaven estretament vinculats. La caiguda i la llarga estagnació de la manufactura tèxtil gironina es va fer notar a Sant Feliu, l'anomenat «port de Girona», que, alhora, havia patit l'impacte de la pesta, la repressió després de l'aixecament de 1640 i els atacs francesos posteriors. Malgrat tot, va participar en el redreç a partir de 1670, substituint l'antiga dependència per una dedicació més gran a la pesca i a la salaó de la sardina i l'anxova per exportar. En contrapartida, es rebien teixits de Narbona, de Montpeller o de Gènova, que, juntament amb altres productes, es distribuïen a l'interior. Blanes i Palamós, amb menys activitat, participaven també en la recuperació a través de l'exportació de productes agroforestals com ara el suro i les castanyes.

En aquest cas, en la relació entre interior i costa, es diferenciava l'àrea més propera d'on procedien la fusta, el suro i els fruits secs, i la més allunyada, vinculada a la xarxa gironina, que proveïa aquell comerç de teixits i de productes 
metal·lúrgics. L'explotació forestal, que ja era important des de mitjan segle XVI, es va refer després de la caiguda ocorreguda a mitjan segle XVII i el suro tornava a sortir cap a Barcelona i als ports de València, Alacant, Màlaga i Cadis, així com alguns de francesos, des de Sant Feliu, però també des de Tossa, Lloret i Blanes 5 . Una part de la fusta era utilitzada pels boters i pels barrilers d'aquelles mateixes poblacions, mentre que una altra part anava cap a València o cap a Itàlia, sobretot des de Blanes. L'exportació d'aquells productes s'intensificà amb l'augment de l'expansió vitícola del segle XVIII.

De la mateixa manera que succeïa al Camp de Tarragona, els fruits secs, especialment les castanyes però també les avellanes, van ser un producte important en la relació entre la producció agrària de zones de la Selva i d'una part d'Osona i el comerç que, des d'aquells ports, es dirigia fonamentalment cap a València. La represa econòmica d'aquella àrea litoral reflectia, doncs, l'articulació amb l'interior rural més o menys proper, la reorientació de la pròpia dedicació i l'aprofitament de nous recursos generats per la pluriactivitat, com podia ser la producció de puntes de Blanes, una part de la qual també s'exportava. El dinamisme d'aquelles viles mostrava, d'altra banda, la relativa autonomia que havien assolit, tant en relació amb Girona com amb Barcelona.

La costa central i la del sud foren els espais del Principat on es manifestà més clarament el redreç per l'estreta relació entre la transformació agrària i el creixement del comerç, tant de cabotatge pel litoral peninsular com d'exportació. Prenem com a exemple dues realitats relativament diferents: Sitges i Vilanova i la Geltrú, poblacions clarament situades dins de la xarxa barcelonina, i Reus i Salou, que, sense formar part directa d'aquell entramat, van participar en la mateixa dinàmica en alguna mesura.

Les viles del Garraf, que ja havien optat, des del segle XVI, per una certa especialització vitícola - la malvasia de Sitges i els vins clarets-, aportaven al mercat barceloní aquests productes juntament amb els de la manufactura del margalló, com eren les escombres, els cabassos i les senalles. S'hi afegien encara cereals propis o dels entorns, fins al Penedès, que abastaven la demanda de la ciutat. A partir de 1670, però, reflectint el creixement de la producció i de l'especialització, el comerç per la Mediterrània va prendre més protagonisme, amb la presència de productes i mercaders genovesos i amb una intensificació de les relacions amb València, Mallorca, Menorca o Eivissa i fins puntualment a l'Atlàntic cap a Anglaterra. Vilanova aportava el vi a Barcelona, mentre que l'aiguardent el comercialitzava per tota la costa catalana. L'interès en l'exportació, tant de l'aiguardent com d'altres productes, va propiciar la inversió de capital barceloní com la de Pau Feu, que construí una fassina a Vilanova i carregava cap a Holanda (Virella, 1990: 24-25).

Finalment, és molt indicativa de tot aquell procés l'evolució que va seguir la vila de Reus i l'estreta relació que va establir amb Salou com a port de sortida. Mentre que la represa de Tarragona, en el seu paper d'enllaç entre València i Barcelona, i com a receptora del blat de la Segarra i de l'Urgell que abastava aquesta ciutat, va ser més lleu i dificultosa, per contra, Reus va registrar un fort

5. ACA. Generalitat, D-50-1417. 
creixement a partir de 1660. En els primers anys del redreç, els productes agraris (el vi, l'aiguardent, les avellanes, l'oli i les garrofes) compartien el protagonisme amb la manufactura de la pell, la sola, que es produïa a la mateixa vila. A partir de 1680, s'intensificava el creixement, centrat ja en l'exportació de l'aiguardent i seguit del vi, les avellanes i les ametlles com a resultat d'una especialització que s'havia estès pel Camp de Tarragona i que s'endinsava cap a l'Urgell i el Penedès (Segarra, 1994; Andreu, 1986). Si abans les sortides s'havien diversificat entre Tarragona, Cambrils i Salou, des d'aleshores es concentraven a Salou, on es gaudia d'exempcions de drets. La destinació principal era l'Atlàntic nord, amb una presència important de vaixells anglesos.

Un aspecte sobresortint en aquest desenvolupament fou sens dubte la participació de comerciants estrangers i de companyies constituïdes a Barcelona, que diversificaven així els seus àmbits d'actuació. Els mercaders reusencs intervenien com a productors d'aiguardent i, en tot cas, com a comissionistes d'aquells, alhora que es dedicaven al comerç interior. Amb tot, s'han de tenir en compte excepcions com la dels Grasses, que també participaven en l'exportació i es convertien en membres de la companyia de Salvador Feliu de la Penya. Si bé l'aiguardent esdevingué el producte principal d'aquell comerç, en l'àmbit mediterrani, els genovesos també embarcaven vi negre, bótes o bescuit. Així mateix, els fruits secs ocupaven un lloc important en la major part de carregaments, amb més volum que el constatat a la costa nord ${ }^{6}$.

L'impuls de l'activitat exportadora també va contribuir a intensificar el comerç cap a l'interior, amb una presència significativa de mercaders aragonesos, que hi cercaven tant productes importats com els que es produïen a la mateixa àrea, en aquest cas, sobretot, els fruits secs i la sola.

Així doncs, en conjunt, el redreç econòmic era inqüestionable a l'àrea litoral i, en la mesura que s'havia aconseguit per la vinculació amb l'interior més proper, els efectes també es feien extensius a un espai més ampli del Principat. Tot plegat contribuiia a crear una articulació més àmplia del territori a través d'una xarxa urbana complexa (Dantí et al., 2011: 52-54).

\section{Condicions per a la revolta}

El redreç s'iniciava en el marc de les conseqüències de la revolució de 1640, del que havia suposat el trencament amb la monarquia hispànica, una guerra de recuperació per a la reintegració, i el resultat de la Pau dels Pirineus. Un context en el qual no es pot deixar de banda que els esdeveniments de Catalunya ocupaven un lloc important dins del conjunt de la política internacional europea (Simon, 2011). En aquest sentit, doncs, la disposició de la monarquia en relació amb Catalunya era determinada per la repressió desencadenada a partir de 1652, que s'havia concretat en la intervenció en les institucions i en l'exigència d'aportacions econòmiques extraordinàries (Torras, 1991: 241-290); per l'objectiu del control

6. ACA. Generalitat, D-23, 915. L'any 1699, el cònsol anglès Joseph Shallet carregava cinquanta quintars d'ametlles de l'Urgell. 
efectiu del territori i, alhora, de la defensa davant de futures amenaces, malgrat les dificultats de portar-la a terme, per la manca de recursos de la hisenda reial; i, finalment, per les guerres successives amb França des de 1667 i fins a 1697, que obligaven i justificaven una presència militar important (Espino, 1999).

Al bell mig del canvi de conjuntura, s'alçà la revolta dels Barretines, entre 1687 i 1690, on confluïen la continuïtat de les causes de conflicte amb la monarquia, amb el rerefons fix de la desconfiança i les circumstàncies particulars del període, que eren alhora econòmiques, socials i polítiques (Kamen, 1979: 11-28; Dantí, 1990). Com es sabut, es tractava d'una revolta pagesa, popular, però no pas d'un més dels aixecaments de subsistències a causa d'una penúria, malgrat que esclatés a l'entorn de la crisi provocada per la plaga de llagosta de 16851687. Fou un moviment encapçalat per pagesos benestants i, per tant, mogut justament per la defensa de l'aprofitament i de la continuïtat de la represa, o si més no de l'estabilitat, en la qual també participaven.

Els Barretines defensaven, al mateix temps, la legalitat de les constitucions pel que es referia als allotjaments militars i a la imposició de drets fiscals nous. Aquells eren els factors que, d'una banda, eren percebuts com a fruit de l'abús i de l'arbitrarietat i, de l'altra, afectaven directament la renda pagesa fins que la malmetien. Va ser el component polític de la revolta entorn del qual s'involucrava les institucions catalanes, especialment la Diputació del General, però també el Consell de Cent, ja que les abocava al compromès decantament de complir amb la mateixa defensa de les constitucions o d'anteposar-hi una fidelitat al rei que era la condició per accedir als càrrecs des del control més gran exercit a partir de 1652.

Un element que cal considerar d'aquella revolta és el gran abast de la mobilització, tot i les divergències de la documentació i la prevenció amb la qual cal prendre aquest tipus d'apreciacions. Una de les causes seria la dels precedents, la continuada tensió i els repetits abusos que els soldats cometien arreu del territori des de 1659 i sense que les queixes fetes als diferents virreis tinguessin cap resposta efectiva (Dantí, 2009: 245-254). La pròpia pressió dels capdavanters va ser una altra de les causes de l'extensió de l'aixecament. Que, referent al setge a la ciutat de Barcelona de 1688, es parli de fins a 18.000 i 20.000 Barretines (algunes fonts ho xifren només en 3.500) i que l'any 1689 tornessin a envoltar la ciutat entre 6.000 i 10.000 homes és la mostra d'una gran coincidència en les motivacions i d'una capacitat d'organització molt notable que ja no s'hauria desfet després del primer alçament de Centelles de 1687 (Alsina, 1987: 79-90; Simon, 1993: 65) ${ }^{7}$.

Una de les qüestions que pensem que els estudis sobre la revolta dels Barretines han ajudat a escatir és la referida al caràcter de les relacions entre Catalunya $\mathrm{i}$ la monarquia durant el regnat de Carles II, a partir d'aquella valoració primerenca

7. Biblioteca de Catalunya, ms. 504. Sucessos de Cataluña, foli 24; ACA. Consell d'Aragó, lligall 240. L'informe fet per la Reial Audiència parla de 10.000 (14 de juny de 1688); Dietari de l'Antich Consell Barceloní, vol. xx, p. 331. Al llibre de memòries de Francisco Gelat, pagès de Santa Susanna, hi consten també 20.000 homes. 
de Reglà que el qualificava de neoforalista i que, per contra, s'ha pogut constatar que fou molt més de continuïtat de la de Felip IV i, en el millor dels casos, d'aproximació a les classes dirigents o de col-laboració necessària (Reglà, 1963: 310-312; Sánchez Marcos, 1983; Ribot, 1999; Gil, 2001).

Resseguirem amb tres textos la síntesi de la visió que els òrgans principals de la monarquia tenien sobre Catalunya en moments diferents, des de la capitulació de 1652 fins a l'acabament de la revolta dels Barretines, on es constata la continuïtat en els criteris polítics i la desconfiança de fons. A la consulta del Consell d'Aragó dirigida a Felip IV, s'hi deia:

Hallándose tan cerca del francés y ellos tan propensos a su perdición, no ha de quedar aquello seguro sin gran prevención y con este sentimiento es necesario ir aplicando los remedios o quedará expuesto a que sucedan nuevos y mayores daños [...] hallándose consentidos y poderosos han de buscar el expediente y camino de llamar a Francia ${ }^{8}$.

A part de la preocupació que aleshores hi havia per una guerra no acabada, la justificació de la repressió es fonamentava en la idea de la persistència del desig de trencament amb la monarquia i de partidaris del suport francès. D'aquell temor, se'n desprendria l'ambivalència de les actuacions posteriors, les mesures de control polític i militar $\mathrm{i}$, alhora, es procurava que no fossin excessives per evitar un nou aixecament.

Malgrat l'aplicació del control de les insaculacions com a mesura repressiva sobre el Consell de Cent i la Diputació del General, la consideració del virrei Bournonville l'any 1684 en relació amb els consellers barcelonins no havia variat a la d'altres textos anteriors a 1640:

[...] lo que en tales sujetos no es novedad, respecto de que su naturaleza les inclina siempre a poner dificultades en todo lo que mira al servicio de Vuestra Majestad 9 .

A la part final de la revolta dels Barretines, el virrei duc de Villahermosa radicalitzava les seves actuacions, alhora que lamentava la fragilitat del poder reial a Catalunya, per aquests motius, reiterava les motivacions d'enfortir la necessària presència militar al Principat, així com l'ús de la repressió com a únic mitjà per impedir nous moviments:

No contemplarlos y que sin apurarlos ni exasperarlos con cosas insoportables, se les haga entrar por lo razonable y asi conviene tratar de despojarles de la posesión en que se hallan de consentimiento y libertad ${ }^{10}$.

8. Correspon a la consulta del Consell d'Aragó de 14 de novembre de 1652, transcrita a Torras, 1991: 50-51.

9. ACA. Consell d'Aragó, lligall 336. Carta de Bournonville a Carles II, 29 de gener de 1684. Reflectia la reticència del Consell de Cent a aportar un nou terç de soldats.

10. Biblioteca Nacional, ms. 2.399. Carta del duc de Villahermosa al comte d'Oropesa (3 de juliol de 1689). 
En los naturales de Cataluña es más poderoso el escarmiento del castigo proporcionado que la tolerancia y sufrimiento, pues ni desengañan ni reprimen ${ }^{11}$.

L'amenaça francesa únicament era, doncs, una raó més, mentre que la preocupació constant era la d'assegurar un domini fonamentat en la presència militar i en el control de les institucions a través del dret de desinsaculació. Un aspecte i l'altre esdevenien les causes de les reivindicacions principals dels Barretines: l'exigència de la reincorporació als seus càrrecs a la Diputació del General dels germans Daniel i Antoni Saiol i de Josep Ciges, i la reducció de la pressió dels allotjaments. L'anàlisi de la revolta en la doble vessant social i política reflecteix tant els efectes del redreç, com els de la repressió sobre les institucions catalanes endegada per la monarquia després de la capitulació de 1652. Resseguirem alguns trets sobresortints de tots dos aspectes.

Tal com s'ha dit, el continuat manteniment de l'exèrcit sobre el territori fou causa, en si mateix, de les limitacions en la represa de l'economia agrària en molts indrets, tenint en compte que la crisi de la primera meitat del segle ja havia tingut com a conseqüència una accentuació de la diferenciació social interna de la pagesia catalana, amb un impacte important de l'endeutament, que comportà una concentració més gran de la propietat i l'augment dels jornalers i dels arrendataris amb poca terra. Les penúries de 1684 a 1687 van accentuar aquella situació. En aquest context, però, amb la revolta, s'imposà la cohesió de la comunitat pagesa per sobre d'aquella diferenciació, per la constatació que la pressió dels allotjaments condicionava el redreç i agreujava la precarietat dels petits pagesos. La bona consideració que rebien els pagesos benestants que encapçalaven la revolta, com ara Enric Torres, de Sant Quirze Safaja; Antoni Soler, de Sant Boi de Llobregat, o Josep Llavina, de Centelles, entre d'altres, que alhora formaven part dels consells municipals respectius, és el reflex que la percepció era la d'una causa comuna, fet que també explica la disponibilitat per mobilitzar-se (Kamen, 1978: 11$)^{12}$.

A l'interior d'aquelles comunitats, però, es posava de manifest el conflicte amb els privilegiats, ja que, per la seva condició, estaven exempts d'allotjament. A part dels que tenien privilegi militar, també gaudien d'exempció, entre d'altres, els ciutadans honrats de Barcelona, els oficials de la Diputació, els familiars del Sant Ofici, els doctors en medicina i lleis i els almoiners de Montserrat. El fet s'agreujava sobretot pel gran volum de títols de ciutadà honrat concedits per Carles II (216). Cal tenir en compte que un nombre significatiu corresponia a pagesos benestants (Morales, 1979: 177). La causa del conflicte era, doncs, que el pes de l'allotjament esdevenia encara més feixuc a l'hora del repartiment.

La conflictivitat antisenyorial ja s'havia accentuat en el marc de la crisi de la primera meitat del segle, davant l'exigència dels senyors per tal de refer la seva

11. BN, ms. 2.402, folis 320-344. Informe del duc de Villahermosa a Carles II (15 de desembre de 1690), transcrit a Dantí, 1990: 206-224.

12. Segons Kamen, fou «L'alçament popular més important ocorregut en els dominis dels Habsburg castellans en el curs del segle XVII». Sobre la condició social dels dirigents Barretines, vegeu Albareda, 1988: 151-170. 
pròpia renda, afectada també per la caiguda de la producció agrària. Amb el canvi de conjuntura, la resistència a alguns drets, sobretot als delmes, i a la recuperació d'altres o al control d'aquells que havien estat cedits als consells municipals, era el reflex tant de l'estagnació que encara patia un sector molt important de la pagesia, com de la percepció que es tractava d'un ròssec per poder accedir al redreç que s'anava albirant, especialment per part dels pagesos benestants. D'altra banda, la posició dels senyors en relació amb els allotjaments, atès que es negaven a qualsevol contribució $\mathrm{i}$ fins estaven en connivència amb el poder reial per utilitzar-los com a mitjà de pressió (cas de Centelles, on s'inicià la revolta dels Barretines), refermava aquell tipus de conflicte (Dantí, 1990: 106-110).

La diferència que es donava entre les poblacions rurals —amb una situació econòmica precària $i$ unes hisendes municipals sovint endeutades - $i$ les viles $i$ ciutats que participaven més clarament en el redreç, s'evidenciava també en la capacitat d'alliberar-se de la càrrega de l'allotjament. En el marc de la revolta, el cas més significatiu seria el de la vila de Mataró, però també els de Moià, l'Hospitalet, Sabadell o Vilafranca del Penedès, que substituïen el manteniment de soldats a canvi del pagament d'una contribució, amb les conseqüències que tenia sobre la resta del territori per haver d'assumir un volum més gran d'exèrcit. Cal tenir present que els allotjaments se situaven majoritàriament a les zones rurals, de manera que el decantament de viles i ciutats fou propiciat per la pressió exercida pels revoltats, mentre que la resistència responia al temor a les conseqüències de l'aixecament i a la desestabilització del redreç que vivien ${ }^{13}$.

Pel que fa als nuclis de la burgesia ascendent, protagonista de la represa, que es pot identificar amb la figura i l'entorn de Narcís Feliu de la Penya, en conjunt, apareixia com a distanciada de la pagesia en relació amb el posicionament davant del poder reial. D'una banda, cercava el suport de la monarquia per desenvolupar els projectes econòmics de clar caràcter mercantilista que pretenia impulsar, amb una estreta relació amb la delegació de la Junta General de Comercio, i, finalment, assolint la creació de la Junta de Comerç de Barcelona el 1692 (Molas, 1977: 240-250). D'altra banda, pel nivell de frau que es cometia en els drets de la Diputació del General, tal com planteja Serra, també s'hauria produït un distanciament, en aquest cas per simple pragmatisme econòmic, en relació amb aquella institució (Serra, 2001: 92).

Malgrat tot, aquell grup social tampoc no s'escapava d'alguns conflictes amb la monarquia, com ara la prohibició d'entrada de mercaderies procedents de França o dels seus dominis, dictada pel virrei duc de San Germán el 1674, que imposava el control de la capitania general sobre qualsevol producte que entrés per mar. Fou considerat, pels mercaders i gremis i pel Consolat, el Consell de Cent i la mateixa Diputació, com una limitació al lliure comerç i causa de contra-

13. ACA. Consell d'Aragó, lligall 211/2. El virrei duc de Villahermosa proposava de reconèixer l'actitud de fidelitat de les ciutats de Tarragona, Girona, Vic i Manresa, com també de les viles de Mataró i Moià. BN, ms. 2402. L'Audiència afegia com a viles lleials, entre d'altres, Reus, Cervera, Tàrrega o Balaguer. 
facció $^{14}$. Per aquella oposició i denúncia, es va arribar a la detenció i a l'empresonament d'alguns botiguers i negociants, com ara Martí Piles, soci de Pau Feu i de Feliu de la Penya, tots els quals eren capdavanters del redreç i persones que després esdevindrien austriacistes destacats ${ }^{15}$.

Encara que es tractava d'un cercle relativament limitat, tampoc no es pot menystenir el fet que alguns membres d'aquella burgesia, com la mateixa companyia Feu-Feliu de la Penya, participaven en el subministrament a l'exèrcit, tal com ha exposat Espino, del qual treien importants beneficis econòmics i el reconeixement per part dels virreis i del monarca, amb la concessió de privilegis de ciutadà honrat o de cavaller (Espino, 1999: 326-332). Entre els diferents àmbits de vinculació amb aquell negoci, hi havia el del pa de munició i el del gra, amb noms destacats com ara la família de flequers dels Colomer, els mercaders holandesos Kies i Jager o algun conseller barceloní, entre d'altres (García Espuche, 2004: 286-312). Aquestes relacions expliquen prou clarament tant el posicionament d'aquella burgesia en contra de la revolta i a favor del pacte, com la satisfacció amb el govern de Carles II.

\section{Entre el conflicte i la fidelitat}

En el mateix marc de tensió, s'hi ha de situar l'equilibri en què es van moure les institucions catalanes, tant la Diputació com el Consell de Cent. Tal com s'ha dit, la repressió política a partir de 1652 s'exercí a través del control de les insaculacions, amb l'objectiu d'assegurar-se la fidelitat i de comprar voluntats (Torras, 1993: 457-468). Després de les primeres depuracions, les desinsaculacions van ser poques, però, en tot cas, es feia palesa la consciència de la dependència reial. El resultat fou el debilitament institucional, si bé no ho va ser fins a l'extrem de deixar de reclamar diverses vegades la recuperació d'aquell dret, amb la invariable resposta negativa fins a les mateixes corts borbòniques de 1701-1702 (Simon, 2011: 69-81). La reclamació es justificava sempre després d'alguna demostració de disponibilitat a les demandes de la monarquia, però mentre es reconeixia amb concessions menors no s'acceptava la més gran, perquè es considerava un element fonamental per al control polític. D'altra banda, la Corona exigia la inclusió d'oficials reials a les bosses de la Generalitat per cobrir-ne ràpidament les vacants, malgrat que fos una contrafacció, cosa que tampoc es deixava de denunciar en cada cas d'habilitació (Ferro, 1987: 248; Serra, 2001: 71-104). Quan aquell dret s'acabà cedint, a les corts de 1705-1706, fou encara a precari.

Així doncs, s'ha plantejat fins a quin punt aquella mesura repressiva havia aconseguit els objectius pretesos, si la Diputació no va deixar en cap moment de defensar les constitucions, encara que es tractés d'una queixa recurrent que anava seguida d'una acceptació resignada de l'incompliment, cas de l'entrada de nou virrei sense haver-se convocat corts i realitzat el jurament de les constitucions per part del rei. En la mateixa línia, s'han de subratllar les manifestacions de suport a

14. Dietaris de la Generalitat de Catalunya, vol. vII, p. 722-724.

15. Dietaris de la Generalitat de Catalunya, vol. vIII, p. 122-123. 
les queixes de consells municipals i particulars pels excessos de l'allotjament i els abusos dels soldats.

En aquest darrer aspecte, però, la identificació amb la defensa de la legalitat s'imposava a la consciència de la dependència del poder reial. Només així es pot entendre el conflicte amb el virrei marquès de Leganés, el 1687, enfrontat també amb la Diputació per altres causes, quan instà la destitució i la desinsaculació d'Antoni i Daniel Saiol, com també de Josep Ciges, coincidint aleshores amb l'inici de la revolta dels Barretines (Simon, 2011: 134-146) ${ }^{16}$. Si bé primer es produiia la intercessió de la resta de diputats, posteriorment, amb la pressió del mateix virrei, s'aconseguia que es manifestessin diferències internes entre els membres de la institució. El criteri reial quedava clar en la carta enviada als diputats després de l'extracció dels que substituïen els destituïts:

[...] havéis hecho extracción de otro diputado ecclesiástico, de otro oydor militar y de otro assesor para servir dichos officios en el trienio corriente, y he querido responderos he tenido particular complacencia de haver sabido los sugetos que han sorteado en lugar de los que he mandado excluhir del exercicio de dichos cargos, fiando, con razón, de vuestra atención y celo que assí vosotros como los nuevamente extractos cumpliréis con vuestras obligaciones en lo que se offreciere de mi servicio y también en mirar por el bien común de essa província ${ }^{17}$.

S'ha de mesurar la força assolida pels Barretines en la mobilització del maig de 1688, alhora que la debilitat de la monarquia, que aconseguia la reintegració d'aquells en els seus càrrecs, malgrat que no canviés el criteri sobre el dret de desinsaculació.

Un altre àmbit en el qual la Diputació no abandonà la defensa, però en què tampoc reeixiria, fou el de les seves finances i, en concret, en el control de la pròpia fiscalitat. La preocupació pel frau va ser constant, sobretot a partir de 1659, però no només no aconseguia el suport reial, sinó que diverses actuacions de la Corona agreujaven l'estat d'aquella hisenda, situació que també repercutia negativament en les sol-licituds successives d'aportacions econòmiques per a les despeses de la mateixa monarquia. La Diputació denunciava l'agreujament del frau, en el qual participaven els seus propis collidors i taulers, particularment el que realitzaven privilegiats i oficials reials en els teixits, on «hi ha gran abús entre personas, així eclesiàsticas com seculars, cabos y ministres de justícia y de la guerra, que no sols se acontentan de tenir dits magatsems de robas forasteras, però encara donan lloch a que en sas casas tingan talers a hont se fabrican robas de seda, oculta y amagadament y sens que manifesten al General» ${ }^{18}$.

Una primera intervenció de la Corona en les finances de la Diputació fou la incorporació de l'impost de nova ampra, amb la conseqüència de la pèrdua d'uns

16. Simon es refereix fonamentalment al plet entre Manuel Llupià i els Alemany-Fontanella.

17. Dietaris de la Generalitat de Catalunya, vol. vIII, p. 919. La carta reial que s'inseria al dietari era del 31 de juliol de 1687.

18. Dietaris de la Generalitat de Catalunya, vol. VIII, p. 530-534. Memorial que es presentava al virrei el 18 de novembre de 1681. 
ingressos que havien de rescabalar el censal de guerra creat l'any 1640, a part de la limitació de la capacitat de gestió de la Generalitat. Una intromissió encara més greu fou la realitzada pel virrei duc de Sessa, el 1670, quan establia que es podria mercadejar indirectament amb productes de països enemics, però sota el control d'oficials de la capitania general que cobrarien un doble dret, per contraban i per entrada, a part del derivat de l'estimació sobre la procedència del producte. En aquest cas, l'actuació perjudicava l'activitat comercial per l'encariment que comportava i, alhora, s'atribuïa una jurisdicció que no li corresponia, a part de la contrafacció que suposava l'establiment d'un nou dret, tal com la Diputació manifestava al virrei:

[...] diuen y representan a Vostra Excel-lència que [...] està expressament disposat no ésser lícit ni permès al capità general de aquest Principat, per si ni ministres alguns, directa o indirectament, palès ni amagadament, ab qualsevol motiu o potestat, imposar, exigir ni fer exigir vectigal algun, imposició ni contribució [...] desitjan los diputats y oïdors acudir a la observansa de sos oficis, procurant que los provincials no sian molestats per ministres y oficials de la capitania general ab la execució de ditas cridas ${ }^{19}$.

Els motius de contrafacció per part de la capitania general es van multiplicar l'any 1674, amb la prohibició d'entrada de mercaderies franceses o que haguessin passat per aquell territori, i se'n va atribuir el control, el registre i la imposició corresponent de penes. D'aquella disposició se'n derivarien, a més, diverses actuacions repressives sobre mercaders catalans (Dantí, 2009: 245-254) ${ }^{20}$. En el mateix procés, els diputats denunciaven el frau que cometien directament els propis oficials de capitania:

Acostuman los officials de la Capitania General, quan venan algunas barcas o fustas ab robas o mercaderias a la platja de la present ciutat, fer desembarcar aquellas y fer-las descarregar en la barraca de dita Capitania General sens haver descarregat aquellas en las casas del General y allí haver pagat los drets a dit General. Y moltas vegades se'n aportan, ditas robas de dita barraca, restant defraudat lo General de sos drets ${ }^{21}$.

D'altra banda, tampoc no eren acceptades algunes mesures proposades per la Diputació per perseguir el frau esmentat, com era la que emparava el diputat eclesiàstic per excomunicar els qui no paguessin els drets fiscals, a part que obligava els membres dels gremis a jurar-ne el compliment. L'any 1681, el virrei duc de Bournonville n'impedia l'aplicació i instava Carles II a desautoritzar l'acord pres per la Generalitat i el Consell de Cent, tal com va fer malgrat que va recollir en la seva pròpia carta la justificació dels diputats «por lo mucho que se necesita deste remedio a causa de lo que cada día se van disminuyendo los dichos d[e]

19. Dietaris de la Generalitat de Catalunya, vol. viI, p. 1438-1440.

20. Dietaris de la Generalitat de Catalunya, vol. viII, p. 124-125. Recull les queixes de mercaders catalans intervinguts per la capitania general, no només en productes que no eren de contraban, sinó també en els llibres de comptes.

21. Dietaris de la Generalitat de Catalunya, vol. vIII, p. 123. 
rechos, de manera que no havrá quien quiera arrendarlos $»^{22}$. Fins i tot amb atribucions que no depenien del poder reial, com ara les butlles papals que permetien l'actuació esmentada, les institucions catalanes no aconseguien imposar-se i s'arribava a la pràctica fallida de les seves finances.

En la vessant de la col-laboració i la fidelitat institucional amb el poder reial, s'ha d'assenyalar la implicació en la defensa, la disponibilitat manifestada tant per la Diputació com pel Consell de Cent per tal d'aconseguir lleves. Fins als anys vuitanta, els diputats atenien les sol-licituds de soldats fins a comprometre's a sortir personalment pel Principat per formar un terç, com succeí amb la demanda del virrei, el 1675, d'enviar més reforços a l'Empordà: «[...] attenent ses senyories a la sobredita carta de sa excel-lència, desitjan acudir al major servey de sa magestad [...] se disposaven per a eixir per Catalunya a solicitar llevas de soldats ${ }^{23}$. Sense qüestionar la fidelitat, l'actitud fou de més prevenció, atès l'augment de dificultats per part de les poblacions a fer qualsevol contribució nova. Amb tot, amb el retorn de la guerra amb França, el maig de 1689, la Generalitat responia la demanda del virrei Villahermosa amb la creació d'un terç de quatre-cents homes i el Consell de Cent amb un de cinc-cents, i el 1691 en feia un altre de tres-cents (Espino, 1999: 250-251) ${ }^{24}$. Tant la Generalitat com el Consell barceloní van continuar aportant terços des de 1694 i fins al final de la guerra, el 1697, tal com ha estudiat Espino, amb la qual cosa es desmenteix la manca de col-laboració catalana (Espino, 1999: 258-264). Així i tot, tampoc no es deixaven de presentar les queixes per la indefensió del Principat a causa de la manca d'acció del virrei Gastañaga davant l'amenaça francesa l'any 1696. La reacció reial fou la desinsaculació de quatre dels sis consellers sortints (Simon, 2011: 224).

Pel que fa a l'actitud de les institucions durant la revolta dels Barretines, dins d'una reiterada manifestació de fidelitat al poder reial i d'estar al marge del moviment, en els anys 1687-1688 la posició dominant va ser la d'oferir-se al virrei per fer d'intermediadors. El Consell de Cent, però, també es manifestà diverses vegades obertament en contra de les actuacions d'excessiva exigència sobre les poblacions per part del virrei, el marquès de Leganés. En la darrera fase, amb la radicalització de la revolta l'any 1689, la Generalitat, el Consell de la Ciutat i el braç militar s'acabaven decantant per un clar col-laboracionisme amb el poder reial a partir de l'acceptació de contribuir al «donatiu» voluntari proposat pel virrei Villahermosa. El canvi fou més evident en el cas de la Diputació, amb manifestacions crítiques i fins menyspreadores cap als Barretines, malgrat que es justifiquessin com una intermediació per evitar mals més greus (Dantí, 1990: 131-138). D'aquella col-laboració, en resultava el reconeixement reial, protocol-lari, amb la concessió, als diputats i als membres del braç militar, del títol d'il-lustres i fidelíssims i, als consellers de Barcelona, del privilegi de cobertura.

22. Dietaris de la Generalitat de Catalunya, vol. VIII, p. 496-497. La carta del rei era de 3 de juliol de 1681.

23. Dietaris de la Generalitat de Catalunya, vol. viII, p. 80.

24. Dietaris de la Generalitat de Catalunya, vol. vIII, p. 1064. 
Amb tot, el reconeixement vers les institucions catalanes també es pot interpretar com un reflex més de la importància d'aquell aixecament i de la debilitat de la Corona, ja que, de fet, les actuacions polítiques posteriors van continuar guiades per la desconfiança i per l'amenaça de la possible vinculació dels revoltats amb França. El duc de Villahermosa, partidari d'una repressió més efectiva quan es plantejaven les excepcions al «perdó general» que finalment es concedí, tensava de nou les relacions amb la Diputació i el Consell de Cent, no pas pel dubte del distanciament amb els aixecats, sinó per l'actitud política que significava que es dirigissin directament al monarca sense considerar el lloctinent. Els «tres comuns» es queixaven de la indefensió de Catalunya davant de la pressió francesa, mentre que Villahermosa considerava que les accions conjuntes d'aquells esdevindrien «un tribunal que no reconozca superior» ${ }^{25}$. D'altra banda, el trencament que s'havia produiit entre els pagesos revoltats i les institucions catalanes faria impossible una nova aliança francocatalana tal com procurava endegar-la l'intendent del Rosselló Ramon Trobat (Jané, 2009: 204-205).

La duresa de la repressió sobre els Barretines no va impedir que encara es produïssin algunes accions el mateix 1690, especialment a l'àrea que havia estat de més mobilització — Osona, el Vallès, el Moianès, el Bages i el Lluçanès — i, posteriorment, al Baix Llobregat, al Penedès i al Garraf, però ja sense la possibilitat de reprendre el moviment (Dantí, 1990: 147-150). La fugida forçada a França d'Enric Torres, Josep Rocafort i Joan Rocabruna, caps dels Barretines, amb alguns seguidors, coincidia ja amb els efectes de la guerra dels Nou Anys. Si la revolta havia accentuat l'animadversió cap a l'exèrcit castellà i cap a aquell poder reial, la guerra generaria alhora una francofòbia creixent.

Si l'acabament de la revolta havia suposat la derrota militar dels pagesos, tot i la reducció temporal de l'allotjament, així com un cert aïllament social per part dels qui encapçalaven el redreç, també havia reflectit la debilitat de la monarquia, en haver d'acceptar la reintegració dels Saiol i els Ciges, com també la relativa moderació en el perdó general amb exceptuats, en no incloure entre aquests els comuns de Centelles i Begues, tal com pretenien Villahermosa i alguns membres del Consell d'Aragó i d'Estat, per temor a un nou aixecament amb el possible suport francès.

Les institucions catalanes s'havien afeblit, especialment la Diputació, en relació amb l'any 1640, com a conseqüència de les mesures repressives aplicades a partir de 1652. Malgrat la persistència del control reial, la desconfiança impedí qualsevol canvi de criteri dels governs de la monarquia sobre la necessària presència militar al Principat, «no siendo menos necesario que para la defensa del enemigo para que se mantenga esta Provincia» ${ }^{26}$. Tot plegat, molt lluny de qualsevol noció de neoforalisme, quan, alhora, en aquells darrers anys del segle, es continuava emprant el recurs de la desinsaculació com a resposta a les queixes

25. BN, ms. 2402, folis 342-343. Així es recollia a l'informe presentat pel virrei Villahermosa a Carles II, amb data de 15 de desembre de 1690

26. BN, ms. 2402, foli 336. Es tractava de la visió que en tenia el duc de Villahermosa l'any 1690, un cop acabada la revolta dels Barretines. 
reiterades d'indefensió fins a l'ocupació francesa de Barcelona. Malgrat tot, tant la Generalitat com el Consell de Cent no deixaren de defensar el compliment de les constitucions i la legalitat que les emparava, encara que fos sempre sense resposta i amb dissidències internes.

La revolta dels Barretines també va afavorir la configuració de la base de l'austriacisme pel que fou la principal àrea d'implantació a la Catalunya interior i per la xarxa de relacions personals que s'establí durant l'aixecament amb aquells membres de les institucions, cas dels Saiol o dels Pinós amb els Puig de Perafita, els Sala o els Moragues de Vic. Uns i altres també van participar en l'apropament que significà el virregnat del príncep Darmstadt, amb qui van mantenir la vinculació quan es tractà del decantament austriacista (Simon, 2011: 227-229).

Així doncs, Catalunya es va moure, en el darrer quart del segle XvII, entre un redreç econòmic important, però no pas sense dificultats, durant el qual es consolidà una relació fonamental entre el món urbà i una part significativa del món rural, i, alhora, una revolta oberta en el camp però amb tensions latents bastant més extenses, on convergien motivacions economicosocials i polítiques. Amb els efectes de les mesures de repressió política endegades per la monarquia a partir de 1652 i mantingudes durant tot el període, les institucions catalanes, encara que estiguessin afeblides, se situaren entre la fidelitat deguda al poder reial i la defensa del compliment de la legalitat pròpia del Principat. Amb tot plegat i les conseqüències de les guerres amb França, es donaven les condicions perquè l'austriacisme pogués arrelar en diferents sectors socials.

\section{Bibliografia}

Albareda, J. (1988). «Els dirigents de la revolta pagesa de 1687-1689: de barretines a botiflers». Recerques, 20, 151-170.

- (1991). «Catalunya a finals del segle Xvir: la continuïtat de la revolta». A: SERra, E. (ed.). La revolució catalana de 1640. Barcelona: Crítica.

AlsinA, J. (1987). «Un interessant manuscrit sobre la revolta dels Barretines». Arrahona, $1,79-90$.

Andreu Sugranyes, J. (1986). Economia i societat a Reus durant la crisi de l'Antic Règim. Reus: Edicions Rosa de Reus.

Català Roca, P. (1987). La plaga de llagosta a Catalunya (1686-1688). Barcelona: Rafael Dalmau Editor.

Codina, J. (1987). Els pagesos de Provençana (984-1807). Barcelona: Publicacions de l'Abadia de Montserrat.

DANTí i Riu, J. (1979). «La revolta dels Gorretes a Catalunya, 1687-1689». Estudis d'Història Agrària, 3, 79-100.

-(1988). Terra i població al Vallès Oriental: Època moderna. Santa Eulàlia de Ronçana: Ajuntament de Santa Eulàlia de Ronçana.

- (1990). Aixecaments populars als Països Catalans 1687-1693. Barcelona: Curial.

- (2003). «L'afebliment de la Generalitat, 1674-1689: fidelitat institucional i incapacitat econòmica». A: Dietaris de la Generalitat de Catalunya. Vol. VIII. Barcelona: Generalitat de Catalunya.

— (2008). «Món rural i món urbà. Els Guàrdia de Castellterçol, paraires i arrendataris del glaç». Pedralbes, 28-II, 887-904. 
— (2009). «Conflictivitat social i revolta després del Tractat dels Pirineus». A: Jané, O. (ed.). Del Tractat dels Pirineus a l'Europa del segle XxI: un model en construcció? Barcelona: Museu d'Història de Catalunya.

Dantí, J. (coord.); Pojada, P.; Gómez Zorraquino, J.I.; Lobato, I.; Gual, V.; Jorba, X.; Serra, E.; Torras i Ribé, J.M.; Alcoberro, A. (2011). Les xarxes urbanes a la Catalunya dels segles XVI $i$ XVII. Barcelona: Rafael Dalmau Editor.

Dantí, J. (coord.); Serra, E.; Gual, V.; Alcoberro, A.; Font, J. (2005). Ciutats, viles i pobles a la xarxa urbana de la Catalunya moderna. Barcelona: Rafael Dalmau Editor.

Duran i Pujol, M. (1985). «L'evolució de l'ingrés senyorial a Catalunya (1500-1799)». Recerques, 17, 7-42.

Duran, M. (2003). «Oferta y consumo de tejidos en Cataluña en la segunda mitad del siglo XVII». Revista de Historia Económica, 21, 61-88.

EsPino, A. (1990). <<Ejército y sociedad en la Cataluña del Antiguo Régimen: el problema de los alojamientos, 1653-1689>>. Historia Social, 7, 19-38.

- (1999). Catalunya durante el reinado de Carlos II. Bellaterra: Universitat Autònoma de Barcelona.

- (2007). Guerra, fisco y fueros: La defensa de la Corona de Aragón en tiempos de Carlos II, 1665-1700. València: PUV.

Ferro, V. (1987). El Dret Públic català: Les institucions de Catalunya fins al Decret de Nova Planta. Vic: Eumo.

Fontana Lázaro, J. (1955). «Sobre el comercio exterior de Barcelona en la segunda mitad del siglo Xvir: Notas para una interpretación de la coyuntura catalana». Estudios de Historia Moderna, 5, 197-218.

Forns i BARDAJí, J. (2004). «Les terres de Lleida en el comerç amb Aragó i Catalunya (1661-1682)». A: VicEDo, E. (ed.). Fires, mercats i món rural. Lleida: Institut d'Estudis Ilerdencs.

García Espuche, A. (1998). Un siglo decisivo. Barcelona y Cataluña, 1550-1640. Madrid: Siglo XXI.

-(2004). Barcelona entre dues guerres: Economia i vida quotidiana (1652-1714). Vic: Eumo.

Gifré i Ribas, P. (1999). «Mercat de la terra i formació de patrimonis agraris (14861720): Una primera aproximació». A: Congost, R. i To, L. Homes, masos i història: La Catalunya del nord-est (segles XI-XX). Barcelona: Publicacions de l'Abadia de Montserrat.

Gil Pujol, X. (2001). «La Corona de Aragón a finales del siglo XVII: A vueltas con el neoforalismo». A: Fernánez Albadalejo, P. (ed.). Los Borbones: dinastia y memoria de nación en la España del siglo XVIII. Madrid: Marcial Pons.

Giménez i Blasco, J. (2001). Mataró en la Catalunya del segle XVII: Un microcosmos en moviment. Mataró: Caixa d'Estalvis Laietana.

Graells, E. (1972). La indústria de claus a Ripoll: Contribució a l'estudi de la farga catalana. Barcelona: Fundació Salvador Vives Casajuana.

Gual I ViLÀ, V. (2007). Poblet senyor feudal. Valls: Cossetània.

Jané Checa, O. (2009). Catalunya sense Espanya: Ramon Trobat, ideologia i catalanitat a l'empara de França. Catarroja-Barcelona: Afers.

KAMEN, H. (1978). «Una insurrecció oblidada del segle XVII: l'alçament dels camperols catalans de l'any 1688». Recerques, 9, 11-28.

Lobato Franco, I. (1995). Compañías y negocios en la Cataluña preindustrial. (Barcelona 1650-1720). Sevilla: Secretariado de Publicaciones. Universidad de Sevilla. 
Martí Fraga, E. (2009). La classe dirigent catalana: Els membres de la Conferència dels Tres Comuns i el Braç Militar (1697-1714). Barcelona: Fundació Noguera.

Martínez Shaw, C. (1981). Catalunya en la carrera de Indias 1680-1756. Barcelona: Crítica.

Mirabet, M. (1989). Els Pallarès de Talarn: Petita noblesa rural. Lleida: Ajuntament de Talarn.

Molas i Ribalta, P. (1977). Comerç i estructura social a Catalunya $i$ València als segles XVII $i$ XVIII. Barcelona: Curial.

Morales Roca, F. (1979). «Privilegios nobiliarios del Principado de Cataluña. Dinastia de Austria. Reinado de Carlos II (1665-1700)». Hidalguía, 153.

Oliva I Ricós, B. (2001). La generació dels Feliu de la Penya: Burgesia mercantil $i$ Guerra de Successió entre el Maresme i Barcelona. Lleida: Edicions de la Universitat de Lleida.

Olivé I Ollé, F. (1989). Valls. De la crisi del segle XVI a la recuperació del segle XVIII. La ciutat, les viles, la comarca: un estudi de la terra i de la seva gent al llarg de l'Antic Règim. Tesi doctoral inèdita. Universitat de Barcelona.

Pladevall i Font, A. i Simon i Tarrés, A. (1986). Guerra i vida pagesa a la Catalunya del segle XVII. Barcelona: Curial.

Reglà CAmpistol, J. (1963). Introducción a la historia de España. Barcelona: Teide.

Ribot García, L. A. (1999). «Carlos II. El centenario olvidado». Studia Historica, 20, 19-43.

Sánchez Marcos, F. (1983). Cataluña y el gobierno central tras la guerra de los Segadores (1652-1679). Barcelona: Edicions de la Universitat de Barcelona.

Segarra i Blasco, A. (1994). Aiguardent i mercat a la Catalunya del segle xviII. Vic: Eumo.

Serra i Puig, E. (1988). Pagesos i senyors a la Catalunya del segle XVII. Barcelona: Crítica.

— (2001). «El pas de rosca en el camí de l'austriacisme». A: Albareda et al. Del patriotisme al catalanisme. Vic: Eumo.

— (2004). «Les Valies de Ciutadilla, Maldà i Maldanell: conreus i propietat a la vegueria de Montblanc (segle XVI)». Homenatge al Dr. Emili Giralt i Raventós. Estudis d'Història Agrària, 17, 901-920.

- (2008). «La propietat. Mercat de la terra i evolució de la renda (segles XVI i XVII)». A: Giralt i Raventós, E. (dir.). Història Agrària dels Països Catalans. Edat Moderna. Vol. III. Barcelona: FCRI-Universitats dels Països Catalans.

SimOn I TARrÉs, A. (1992). «Els anys 1627-1632 i la crisi de Catalunya en el segle XVII». Estudis d'Història Agrària, 9, 157-180.

-(1993). Pagesos, capellans i industrials de la Marina de la Selva. Barcelona: Curial.

-(2011). Del 1640 al 1705: L'autogovern de Catalunya i la classe dirigent catalana en el joc de la política internacional europea. València: PUV.

Torras i RibÉ, J. M. (1991). «El projecte de repressió dels catalans de 1652». A: SERRA, E. (ed.). La revolució catalana de 1640. Barcelona: Crítica.

- (1993). «El control polític de les insaculacions del Consell de Cent de Barcelona (16521700)». Pedralbes, 13-I, 457-468.

Vilalta, M. J. (1990). Balaguer a la Catalunya moderna. Lleida: Pagès.

VILAR, P. (1966). Catalunya dins l'Espanya Moderna. Vol. II. Barcelona: Edicions 62.

Virella i Bloda, A. (1990). L'aventura ultramarina de la gent de Vilanova $i$ la Geltrú $i$ la nissaga dels Samà. Vilafranca del Penedès: Museu de Vilafranca. 